\title{
Children's online learning during COVID-19 pandemic: experiences and satisfaction encountered by Indian parents
}

\author{
Hepsi Bai Joseph ${ }^{1 *}$, Sandhiya Kuppuswamy ${ }^{1}$, Asha Prabhakar Shetty ${ }^{1}$
}

\begin{abstract}
Background: Online learning by children is pressure for children as well as parents. The Covid-19 lockdown was ended up putting much stress on parents in India. The current study aimed to assess the parental experience and satisfaction on online learning for their children during Covid -19 pandemic lockdown.
\end{abstract}

Methods: A cross-sectional web-based survey was conducted among 300 parents of children who attended online learning during the COVID -19 pandemic lockdown. The data was collected using the snowball sampling technique. The survey tool consists of a sociodemographic questionnaire, self-report scales on parent's satisfaction and experiences. The collected data were analyzed using descriptive statistics, including mean, frequency, percentage, and inferential statistics such as the Chi-square test.

Results: Out of 300 parents surveyed, $72 \%$ were mothers, $65.6 \%$ of children who attended online classes were from primary class, through zoom platform $(52.2 \%)$ using an android mobile phone $(71.1 \%)$ for a mean duration of $180 \pm 30$ minutes. $80.4 \%$ of parents preferred the traditional learning method comparing to online classes for their children. More than half $(52.2 \%)$ of parents reported that they were partially satisfied with children's online learning, whereas $26 \%$ were not satisfied. More than half of the parents $(61.1 \%)$ experienced a great challenge and burden of online learning.

Conclusion: Parents were worried that prolonged exposure to screen devices in online learning might affect child health's visual, physical, and psychological aspects.

Keywords: Parental Satisfaction, Experience, Online Class, Covid-19 Pandemic, Lockdown, India

\section{Background}

Preceding years, online education of young children using digital devices and technologies was debated among educators, parents, scholars, stakeholders, and policymakers [1]. It was discussed that while digital learning would present the advantage of assisting the young children in appreciating and understanding various concepts and abstracts with the involvement of critical thinking and problem-solving activities, it may also prove to be disadvantageous as exposing the young children to online learning might affect their social and emotional readiness to school [2]. However, the demand for online education was not much utilized in the education system before the covid-19 pandemic. As the covid-19 pandemic was

*Correspondence: nurs_hepsi@aiimsbhubaneswar.edu.in

${ }^{1}$ College of Nursing, All India Institute of Medical Sciences, Bhubaneswar, Odisha, India.

Full list of author information is available at the end of the article declared as a public health emergency by the World Health Organization (WHO), the education system shattered universally. In order to respond and to break pandemic spread universally, facility restrictions and closures were implemented by all the nations. According to United Nations Education Scientific and Cultural Organization, the education system worldwide got affected by ninety percent of the world's student population as a victim and threatened students' future education rights [3]. This was highly essential to motivate social distancing and ineffective transmission of this contagious virus [4]. As an alternative way, all schools and universities adopted various teaching methods through the internet. Various online resources, including online libraries, video lectures, online channels, and television broadcasts, were introduced in various countries to continue education [5]. Universal school closures resulted in a shift from the traditional classroom to remote learning environments. Unfortunately for this sudden shift of 
education process, the teachers, families, and students were unprepared; the role of parental involvement in engaging and assisting at various levels and type of e-learning was the prime need.

\section{Pandemic and Remote learning in India}

The Indian Government too announced nationwide lockdown and advised to continue the education via E- mode. Schools and universities-initiated learning through digital mediums to manage such crises. Amid the pandemic, physical, mental, and financial resources were in high demand for parents to fulfill children's online education. Parents' physical presence throughout the online classes, finance in the procurement of a smartphone with internet facility and assist, support online classes for children without proper instructions and guidelines were significant challenges to handle. The pandemic scenario placed the burden on caregivers and parents by supporting the children with alien technology, assisting in the new learning environment, providing digital technologies. In addition, parents took the role of secondary teachers by clarifying their doubts, recharging the internet for remote learning at home. This was a new experience for the parents, and there was a wide gap in the literature on this topic [6]. In his pre-pandemic survey, Borup J. [7] identified the various role of parents in elearning as organizing and managing children's schedules, monitoring, and motivating child's engagement, nurturing relationships, interacting, and instructing children as needed. Unfortunately, it was the first attempt Indian parents to assist children in virtual learning during the covid pandemic from March 2020. Moreover, it was a new experience for them without prior guidance. It is worthy of studying their experiences and concerns with students and parents concerning educational, physical, and psychological for the comprehensive enhancement of its development in the future. In India, the 2nd upsurge of Covid-19 continued after a year of pandemic and settled by the second half of 2021. Schools and universities are still in a dilemma with the reopening plan. Irrespective of the situation, the education system should also remember the pandemic experiences even after getting rid of the pandemic. Such a health emergency can knock anytime in the future leads to furthermore, high chance of getting school closures. Hence, evaluating parent's experience during this situation would help prepare better to handle online learning strategies [8]. Therefore, the researchers are interested in studying the parents' experience and satisfaction with children's remote learning at the residence during the COVID-19 pandemic.

\section{Methods}

\section{Participants}

A web-based survey using a cross-sectional design was conducted among 300 Indian parents of children from academic grade 1st to 12th attending remote learning during the Covid-19 pandemic. Data were obtained during the first wave of the covid-19 pandemic between July to December 2020. The study covered parents of children attending remote learning during the covid-19 pandemic. Three hundred and eighty respondents filled the proforma, where only 300 were complete.

\section{Inclusion criteria}

The study included parents of school children who attended remote learning during the covid-19 pandemic and the parents who had internet facilities to access through WhatsApp, Facebook, and e-mail.

\section{Inclusion criteria}

The parents excluded parents of children attending remote learning at the collegiate level; parents had children who attended remote learning during the covid-19 pandemic but could not read and respond to the questionnaire in English.

\section{Instrument}

The present study used self-report tools consisted of a sociodemographic questionnaire to collect information of the parents and children, including parental role (father/mother), working status, educational qualification, child's academic grade, device and online platform used, duration of the online class in a day. A self-report scale was used to measure parental satisfaction on children's remote learning during the COVI-19 pandemic, which consists of five items, including "satisfaction on child's study behavior during online class", "the achievement of learning objectives during online class", "teacher-student interaction during online class", "quality of teaching in online class" and the fifth question was devoted to exploring the "overall satisfaction of parents towards online learning". Parents responded to $\mathrm{h}$ their children's remote learning satisfaction $\mathrm{g}$ as "Well satisfied, partially satisfied, and not at all satisfied" for those five questions. Frequency and percentage were employed to analyze each item on the satisfaction of parents. A self-report scale comprising ten items with a "Yes/ No" option was recruited to identify parents' experience on children's remote learning. Statements included were parents experience of "Assisting online classes for my child affect my household work," "Assisting online classes for my child affect my household work," "I need to recharge extra for the internet," "My child is not attentive during online classes", "My presence is needed from start to end during my child's online class", "My child finds it difficult to cope up with online classes", "The home environment is not comfortable for attending online class for my child", "My child finds difficulty in the completion of assignments, homework due to the online mode of teaching" and so on

\section{Reliability and validity}

Both the self-report scale found valid and reliable. The split-half method was employed to determine the reliability, and it was established for the parent's satisfaction tool $(r=0.85)$ and the parent's experience tool $(\mathrm{r}=0.90)$. The tools were submitted to five experts for content validation, and the validity was calculated by the number of experts agreeing on the relevancy of each item, divided by the total number of experts. The content validity index (CVI) for the tool was 0.88 . The tools were prepared in English. Five parents were selected to assess the readability and found the tools were readable. A web-based pilot survey was conducted among 15 parents to determine the tools' clarity, relevance, and acceptability, and they were not included in the main study.

\section{Data Collection Procedure}

After obtaining ethical permission the researchers planned to collect data through an online platform due to the pandemic situation using a Google Form, with a consent form appended to 
it. The sampling technique adopted was snowball sampling to locate the responders. The link was forwarded to people apart from the first point of contact. On clicking the link, the participants got auto directed to the study's detail and consent on receiving and clicking the link. Once the participants agree to participate, they need to fill up the baseline information of the parents and remote learning characteristics followed by remote learning experience and its satisfaction tool.

\section{Statistical analysis}

The received data were coded and entered in a Microsoft excel sheet and analyzed using R software. Descriptive statistics were used to estimate the parental experiences and satisfaction towards remote learning. Inferential statistics, Chi-square test, was used to find the association between parents' overall satisfaction with characteristics of parents.

\section{Results}

Out of 300 surveyed parents $(72.1 \%)$, were mothers, graduates (47.8\%), employed (78.7\%), from the health field (32.6\%). Moreover, more than half of the respondents $(54.8 \%)$ were attending jobs in the pandemic lockdown (Table 1).

Table 1. Background information about parents $(n=300)$

\begin{tabular}{|l|l|}
\hline Parental characteristics & $\mathbf{N}(\%)$ \\
\hline Parental role in the online survey & \\
\hline a) Father & $84(27.9)$ \\
\hline b) Mother & $216(72.1)$ \\
\hline Parental educational status & \\
\hline a) School & $28(9.3)$ \\
\hline b) Diploma & $16(5.4)$ \\
\hline c) Graduate & $113(37.5)$ \\
\hline d) Postgraduate & $143(47.8)$ \\
\hline Parents working status & \\
\hline a) Working & $236(78.7)$ \\
\hline b) Not working & $64(21.3)$ \\
\hline Parents working field & \\
\hline a) Health field & $98(32.6)$ \\
\hline b) Teaching field & $76(25.3)$ \\
\hline c) Business & $28(9.3)$ \\
\hline d) Daily wage & $34(11.4)$ \\
\hline e) Housewife/ Homemaker \& others & $64(21.0)$ \\
\hline Parents Attending work during the lockdown. & \\
\hline a) Yes & $165(54.8)$ \\
\hline b) No & $135(45.2)$ \\
\hline
\end{tabular}

Most of the parents (53.5\%) had single child took part in remote learning, and most of the children were studying in primary class (65.6\%). Besides, sixty-nine percentage of mothers accompanied their children's remote learning, using android mobile $(71.1 \%)$, in Zoom app (52.2\%).
Nearly half of the parents $(50.2 \%)$ did not face any difficulty sharing digital devices as they had a single child, whereas 84 (27.9\%) parents had problems sharing devices for their children during remote learning (Table 2).

Table 2. Child's remote learning characteristics $(\mathrm{n}=300)$

\begin{tabular}{|c|c|}
\hline Remote learning characteristics & $\mathbf{N}(\%)$ \\
\hline \multicolumn{2}{|l|}{ No of children attending online classes in a home } \\
\hline a) 1 & $161(53.5)$ \\
\hline c) & $116(38.9)$ \\
\hline d) & $15(5.0)$ \\
\hline d) $\quad$ More than 3 & $8(2.6)$ \\
\hline \multicolumn{2}{|l|}{ Child's education } \\
\hline a) Primary class & 197(65.6) \\
\hline Middle school & $72(23.9)$ \\
\hline High School \& secondary & $31(10.5)$ \\
\hline \multicolumn{2}{|l|}{ A person accompanied during online class } \\
\hline a) Father & $56(17.6)$ \\
\hline Mother & $206(68.8)$ \\
\hline Other & $41(13.6)$ \\
\hline \multicolumn{2}{|l|}{ The device used for attending the online class } \\
\hline a) Mobile phone (Android) & 214(71.1) \\
\hline Tablet/I pad & $22(7.3)$ \\
\hline Laptop & $55(18.6)$ \\
\hline d) Desktop & $9(3.0)$ \\
\hline \multicolumn{2}{|l|}{$\begin{array}{l}\text { The platform used for online learning for } \\
\text { children }\end{array}$} \\
\hline a) Zoom app & $157(52.2)$ \\
\hline Cisco WebEx & $23(8.0)$ \\
\hline Google meet & $55(18.3)$ \\
\hline d) Others & $65(21.5)$ \\
\hline \multicolumn{2}{|l|}{$\begin{array}{l}\text { Status of sharing the digital device for the online } \\
\text { class }\end{array}$} \\
\hline $\begin{array}{l}\text { a) No problem, I have a single child to attend the } \\
\text { online class }\end{array}$ & $150(50.2)$ \\
\hline $\begin{array}{l}\text { b) Yes, I have problem sharing devices for my } \\
\text { children }\end{array}$ & $84(27.9)$ \\
\hline $\begin{array}{l}\text { c) No, I have adequate devices for each child to } \\
\text { attend online classes }\end{array}$ & $66(21.9)$ \\
\hline
\end{tabular}

Table 3 showed that more than half $(50.5 \%)$ of the parents were partially satisfied with online learning in terms of the child's study behavior, achieving learning objectives in every class (54.7\%), teacher-student interaction (36.0\%), and quality of teaching $(50.0 \%)$. Moreover, $20.0 \%$ of the parents showed overall satisfaction with children's online learning compared to $50.0 \%$ and $30 \%$ who were partially satisfied and not at all satisfied, respectively.

Table 3 Parents satisfaction with their children remote learning $(\mathrm{n}=300)$

\begin{tabular}{|c|c|c|c|c|}
\hline No. & Items & $\begin{array}{c}\text { Satisfied } \\
\mathbf{N}(\%)\end{array}$ & $\begin{array}{c}\text { Partially satisfied } \\
\mathbf{N}(\%)\end{array}$ & $\begin{array}{c}\text { Not satisfied } \\
\mathbf{N}(\%)\end{array}$ \\
\hline 1 & Study behavior of child during online class & $86(28.9 \%)$ & $152(50.5 \%)$ & $62(20.6 \%)$ \\
\hline 2 & Learning objectives achieved in every class & $84(28.3 \%)$ & $164(54.7 \%)$ & $52(17 \%)$ \\
\hline 3 & Teacher-student interaction in an online class & $104(35 \%)$ & $108(36 \%)$ & $88(29 \%)$ \\
\hline 4. & Quality of teaching online & $86(29.2 \%)$ & $149(50 \%)$ & $65(20.8 \%)$ \\
\hline 5 & The overall satisfaction of the parents towards the children's online learning & $60(20.0 \%)$ & $150(50.0)$ & $90(30.0 \%)$ \\
\hline
\end{tabular}


Table 4 showed that more than two-third of the parents $(69.3 \%)$ reported due to their job, they have to depend on others for assisting/accompanying children for an online class. Parents experienced their presence required to be with children all the time during children's online classes, and $61.1 \%$ of parents experienced home-schooling as a great challenge and burden to them. More than half of the parents $(60.5 \%)$ reported that their children found it difficult to cope with online classes.

Table 4: Parental experience on remote learning for their children during covid-19 pandemic lockdown $(n=300)$

\begin{tabular}{|l|l|l|}
\hline Parental Experiences & $\begin{array}{l}\text { Yes } \\
\mathbf{N}(\%)\end{array}$ & $\begin{array}{l}\text { No } \\
\text { N (\%) }\end{array}$ \\
\hline $\begin{array}{l}\text { Assisting online classes for my child } \\
\text { affect my household work. }\end{array}$ & $165(5.5)$ & $135(44.5)$ \\
\hline $\begin{array}{l}\text { For my child's online class, I need to } \\
\text { recharge extra for the internet }\end{array}$ & $146(49)$ & $154(51.0)$ \\
\hline $\begin{array}{l}\text { My child is not attentive during online } \\
\text { classes. }\end{array}$ & $138(46.6)$ & $162(53.4)$ \\
\hline $\begin{array}{l}\text { I have to be there all the time from } \\
\text { beginning to end during my child's } \\
\text { online class. }\end{array}$ & $188(63.4)$ & $112(36.6)$ \\
\hline $\begin{array}{l}\text { Due to my job, I am unable to help my } \\
\text { child in an online class }\end{array}$ & $210(69.3)$ & $90(30.7)$ \\
\hline $\begin{array}{l}\text { Due to my job, I have to depend on } \\
\text { others to assist/accompany my child } \\
\text { for an online class due to my job. }\end{array}$ & $164(55.6)$ & $136(44.4)$ \\
\hline $\begin{array}{l}\text { The home environment is not } \\
\text { comfortable for attending online } \\
\text { classes for my child. }\end{array}$ & $132(44.8)$ & $168(55.2)$ \\
\hline $\begin{array}{l}\text { Home-schooling is a great challenge } \\
\text { and burden for me. }\end{array}$ & $186(61.1)$ & $114(38.9)$ \\
\hline $\begin{array}{l}\text { My child finds it difficult to cope up } \\
\text { with online classes. }\end{array}$ & $178(60.5)$ & $122(39.5)$ \\
\hline $\begin{array}{l}\text { My child finds difficulty in the } \\
\text { due to the online mode of teaching. }\end{array}$ & $155(52.7)$ & $145(47.3)$ \\
\hline
\end{tabular}

\section{Discussion}

Parents satisfaction with children's remote learning

The COVID-19 pandemic entirely changed many directions of our lives. Furthermore, social distancing and lockdown policies have markedly derailed usual educational practices. Consequently, there was an urgent need to revolutionize and execute substitute education as online or remote learning for children. Regarding parent's satisfaction with children's remote learning, nearly half of the parents were partially satisfied with their children's remote learning study behavior (50.5\%), achieving learning objectives in every class (54.7\%). Concerning teacher-student interaction, $36 \%$ of parents were partially satisfied, and around $50 \%$ of parents were also somewhat satisfied with the quality of teaching through remote learning. Similarly, studies found that parental belief in remote learning for their children was less effective. They also believed that remote learning lacked in the learning environment and social interaction to entertain children, resulting in deprived knowledge [8]. Due to lockdown, there was a sudden shift from traditional learning to remote learning. Parents have not prepared for themselves, their children, and the environment.
On top of that, the lack of parental and students' orientation in handling technology could explain why Indian parents are not completely satisfied with their children's remote learning. Moreover, a significant number of schools have not even considered it. The findings reported by the parents might be due to their inexperience with this remote learning. As the day goes, parents and children might be acquainted with the new scenario. Moreover, children's early childhood practices and outdoor activities (free play) got arrested because of the covid 19 pandemics. Arnott and Yelland [2] stated that challenges remain in our understanding of childhoods in the 21 st century and integrating new technologies in children's learning cultures. The use of digital technology by young children was inappropriate and induced confusion for those seeking digital technologies into young children's learning [9-11]. Hence, it's essential to utilize digital technology productively and hasslefree for learning purposes. Erdogan NI et al. [10] and House R. [11] emphasized the reconceptualization of "childhood" and "play" in the digital age in order to support children, parents, and teachers to use new technologies better. Besides, most children were from primary class, and parental expectations towards children's study behavior, interactions, quality teaching, and learning might be disappointing due to the home environment, new to technology. Sharma and Kiran [12] also found in India that parents of children who studied in primary class were less satisfied than children studying in higher and higher secondary classes. Furthermore, the school's effectiveness in handling doubts, learning atmosphere, and help in remote learning technology positively influenced the parents' general satisfaction with remote learning [13]. In addition, lack of interactivity and social isolation as the parents' primary shortcomings of remote learning [14]. School authorities have not looked into these matters even though enormous advancements occurred in online and digital technology. As it is understood, lack of interactivity and social isolation was the disadvantage of remote learning. It's prime time to research interventions to overcome such challenges to protect children's psychological health. More than half of the participants were partially satisfied $(50.0 \%)$ with remote learning of their children, whereas $30.0 \%$ of parents were not all satisfied. During the lockdown, a survey conducted in the United Kingdom revealed that nearly half of parents were dissatisfied with their child's development and progress since lockdownsocial interaction with teachers and missing their friends, reported by $82 \%$ of children [15]. Due to lack of motivation and boredom in studies, most parents were worried that their child's education had been set back [16]. Correspondingly, the parents' overall satisfaction was associated with the remote learning support rendered by the school, instructional programs, and social communications [17]. In a survey report from India by Kumar A and Kumar S [18] in 2020, a parent stated that home learning could not substitute classroom learning. It has its drawbacks, such as the absence of socialization and no direct interaction with teachers and peers. Parents' role has been extended and transferred from parents to teachers, and they had experienced difficulty teaching new academic aspects from home to younger children. Certain factors like willingness to online classes, weekly timing, outputs as offline classes, equipment, syllabus contents, health hazard, parents' involvement, disturbance in parent's job, class activities, and 
favor of blended learning under an exceptional circumstance just like a pandemic, COVID-19 also related with parent's satisfaction [19].

\section{Experience of Indian parents on remote learning}

School Education has been badly hit due to the outbreak of the corona pandemic, with millions of students stranded at home, staring at the screens, and receiving instruction passively. Covid-19 has caused massive disruption with tough challenges for the entire education system across the world. Since Indian teachers and students are habituated to daily meetings and interactions carrying out the teaching and learning activities in the classroom, it is challenging to engage young children [20]. Covid-19 pandemic stimulated a widespread, abrupt, and the intense digital revolution in the community. It forced schools and families to adopt an unexpected digital surge in everyone's day-to-day life journey. Abruptly the whole young parent community had to initiate to handle and cope with online-digital tools to facilitate their offspring in remote learning [21]. Parents agreed that they must assist their child's remote learning that affects their household work. Most of the parents accompanied their children from beginning to end of an online class. Most of the employed parents expressed that they need to depend on others to assist their children's remote learning and felt they could not help their child in an online class. Mothers who looked after household chores in the absence of a maid or cook and sharing time with children's online classes struggled a lot during the lockdown period. It is predominantly tricky for working parents, particularly those working in the health care sector; they need to balance both. This situation emotionally and psychologically drained them. On the other hand, remote learning is an opportunity for parents to spend more time with children and understand their learning abilities, and it may be applicable for non-working parents [18]. Nearly half of the parents $(49.0 \%)$ had experienced difficulty recharging extra for the internet. There was a need for additional smartphones or other digital devices to attend the remote learning and recharge extra for internet for those parents who had more than one school-going child at home. Moreover, there is much more challenge for the parents in procuring digital gadgets and providing network connectivity in rural areas. Indian Government implemented another strategy to cover urban and rural students without network or smartphone facilities by telecasting online classes in a scheduled way from academic grade I to grade XII to all states of India. The sad part of this strategy implementation furthermore challenging because the Economically Weaker Section (EWS) of the society were unable to explore these online/telecasted resources due to unavailability of required infrastructure, including television, laptop, tablets, smartphone, internet, and electricity facility for those children residing in rural, hilly, and tribal areas [21]. Parents also shared that their children faced difficulty completing assignments and homework due to their online learning mode. This was evident in not only school children but also collegiate level students [22]. Parents found the hasty closure of the educational institutions quite distressing and worried about their children's daily schedule. Parents understood that the systematic practice of weekdays schedule was possible only through schools. This facilitated children's understanding of the value of time, schedule, and assignment completion within the stipulated time [23]. A study conducted among Indonesian parents also revealed that parents had concerns about learning outcomes, balancing responsibilities, accessibility, and learner motivation [24]. Students should be encouraged to use their textbooks and notebooks and avoid all digital devices for homework. Handling online technology by inexperienced parents can keep in touch with fellow parents without a parental orientation program. Parents felt their children were not attentive during online classes and engaged in prolonged screen time. Parents shared their concerns about the lengthy screen time of engaging in digital gadgets. In addition to online learning, they can be involved in old teaching techniques with a copy of worksheets and engage them in the reading paper, books, and online so that screen time can be limited. "Digital quarantine" also helped them reduce distractions and focus on their classes [25]. The present study's limitation includes the small sample size, and the online survey may not represent the overall parents residing in the semiurban, rural, hilly, and tribal areas. Factors influencing parental satisfaction, perception need to be studied for better understanding. Socially desirable bias may result from online surveys, and it is better to research child's and teacher's satisfaction towards remote teaching and learning. The study's strength is that no such research has been reported from India related to parental satisfaction, experience on remote learning. The study revealed working parents' experience, especially from the health field, their concerns, and their online learning challenges.

\section{Conclusion}

Even though remote learning is gaining popularity, it was observed that Indian parents faced challenges and problems during its implementation for their children during the covid pandemic. Parents were not ready to accept remote learning than traditional classroom teaching methods due to sudden impose. Parents were concerned about children's future education, general health, vision, and teacher peer relationships. The success of remote learning relies upon the cooperation of the school authority, teachers, parents, students, and the environment. Conducting parent-teacher meetings online and listening to parental concerns and school management frame strategies do not burden the children and parents with online classes and exams.

\section{Abbreviation}

COVID-19: Corona Virus Disease -19; WHO: World Health Organization; UNESCO: United Nations Education Scientific and Cultural Organization; EWS: Economically Weaker Section

\section{Declaration}

Acknowledgment

None.

\section{Funding}

The authors received no financial support for their research, authorship, and/or publication of this article.

Availability of data and materials

Data will be available by emailing

nurs_hepsi@aiimsbhubaneswar.edu.in 
Authors' contributions

All authors contributed to the study's conception and design. Hepsi Bai Joseph (HBJ), Sandhiya K (SK) performed material preparation, data collection, and analysis. Hepsi Bai Joseph (HBJ), and Sandhiya K (SK), wrote the first draft of the manuscript. Asha P Shetty (APS) revised it critically for important intellectual content. All authors commented on previous versions of the manuscript. All authors substantially contributed to the study and approved its submission.

Ethics approval and consent to participate

We conducted the research following the Declaration of Helsinki. The ethical permission was obtained from the Institutional Ethics Committee of AIIMS Bhubaneswar (project no. T/IM-NF/Nursing/2020/66)

Consent for publication

Not applicable

Competing interest

The authors declare that they have no competing interest.

\section{Open Access}

This article is distributed under the terms of the Creative Commons Attribution 4.0 International License (http://creativecommons.org/licenses/by/4.0/), which permits unrestricted use, distribution, and reproduction in any medium, provided you give appropriate credit to the original author(s) and the source, provide a link to the Creative Commons license, and indicate if changes were made. The Creative Commons Public Domain Dedication waiver (http://creativecommons.org/publicdomain/zero/1.0/) applies to the data made available in this article, unless otherwise stated.

\section{Author details}

${ }^{1}$ College of Nursing, All India Institute of Medical Sciences, Bhubaneswar, Odisha, India

Article Info

Received: 07 August 2021

Accepted: 07 September 2021

Published: 22 September 2021

\section{References}

1. Aubrey C, Dahl S. A review of the evidence on the use of ICT in the Early Years Foundation Stage.2008. Retrieved from the University of Warwick, Coventry: http://www.becta.org.uk

2. Arnott L, Yelland NJ. Multimodal lifeworlds: Pedagogies for play inquiries and explorations. Journal of Early Childhood Education Research. 2020 Feb 29;9(1):124-46 Retrieved from https://jecer.org/multimodal-lifeworlds-pedagogies-for-playinquiries-and-explorations/

3. Edwards S, Skouteris H, Rutherford L, Cutter-Mackenzie A. 'It's all about Ben10 $10^{\mathrm{TM}}$ : children's play, health and sustainability decisions in the early years. Early Child Development and Care. 2013 Feb 1;183(2):280-93. doi: 10.1080/03004430.2012.671816

4. UNESCO. COVID-19 educational disruption and response.2020. Retrieved from https://en.unesco.org/news/covid-19-educationaldisruption-and-response.

5. Viner RM, Russell SJ, Croker H, Packer J, Ward J, Stansfield C, et al. School closure and management practices during coronavirus outbreaks including COVID-19: a rapid systematic review. The Lancet Child \& Adolescent Health. 2020 May 1;4(5):397-404. http://dx.doi.org/10.1016/S2352-4642(20)30095$\mathrm{X}$

6. El Firdoussi S, Lachgar M, Kabaili H, Rochdi A, Goujdami D, El Firdoussi L. Assessing distance learning in higher education during the COVID-19 pandemic. Education Research International. $2020 \quad$ Oct;2020. https://doi.org/10.1155/2020/8890633

7. Borup J. Teacher perceptions of learner-learner engagement at a cyber high school. International Review of Research in Open and Distributed Learning. 2016;17(3):231-50. https://doi.org/10.19173/irrodl.v17i3.2361

8. Hodges C, Moore S, Lockee B, Trust T, Bond A. The difference between emergency remote teaching and online learning. Educause review. 2020 Mar 27;27(1):1-9. Retrieved from https://er.educause.edu/articles/2020/3/the-difference-betweenemergency-remote-teaching-and-online-learning

9. Dong C, Cao S, Li H. Young children's online learning during COVID-19 pandemic: Chinese parents' beliefs and attitudes. Children and youth services review. 2020 Nov 1; 118:105440. https:// doi. org/10. 1016/j. child youth. 2020. 105440.

10. Erdogan NI, Johnson JE, Dong PI, Qiu Z. Do parents prefer digital play? Examination of parental preferences and beliefs in four nations. Early Childhood Education Journal. 2019 Mar;47(2):131-42.

11. House R. The inappropriateness of ICT in early childhood: Arguments from philosophy, pedagogy, and developmental research. In Contemporary debates in childhood education and development 2012 Jun 14 (pp. 119-134). Routledge.

12. Sharma I, Kiran D. Study of parent's satisfaction for online classes under lockdown due to COVID-19 in India. Journal of Statistics and Management Systems. 2021 Jan 2;24(1):17-36.

13. Khurana C. Exploring the role of multimedia in enhancing social presence in an asynchronous online course (Doctoral dissertation, Rutgers University-Graduate School-New Brunswick). 2016. https://doi.org/10.7282/T3N018Q3

14. Cathy Parnham. Nearly half of parents unhappy with remote learning during lockdown -Education Technology.2020. https://edtechnology.co.uk/headlines/nearly-half-of-parentsunhappy-with-remote-learning-during-lockdown/

15. Sharma, K.Why online classes may not be such a good idea after all, especially for kids. The Print. 2020. https://theprint.in/india/education/why-online-classes-may-not-besuch-a-good-idea-after-all-especially-for-kids/406979/

16. Warner Butz, C. Student and parent satisfaction with online education at the student and parent satisfaction with online education at the elementary and secondary levels elementary and secondary levels. 2020. https://doi.org/10.25669/p2p9-49f9

17. Chakrabarthy R. How online courses are a boon for mothers juggling jobs, chores and homework during lockdown.2020. https://www.indiatoday.in/education-

today/featurephilia/story/how-online-courses-are-a-boon-foroverworked-parents-during-lockdown-1671038-2020-04-25

18. Kumar A, Kumar S. Factors determining the parents' satisfaction for online primary education during a pandemic (COVID-19). IOSR Journal of Humanities and Social Science 2020. 25, 27-35. https://doi.org/10.9790/0837-2508052735

19. Malik S, Tyagi HK. A study of parent's opinion on online teaching in Delhi-NCR schools. Indian Journal of Science and 
Technology. $2020 \quad$ Dec 3;13(42):4351-63. https://doi.org/10.17485/IJST/V13I42.1664

20. Aliyyah RR, Rachmadtullah R, Samsudin A, Syaodih E, Nurtanto M, Tambunan AR. The perceptions of primary school teachers of online learning during the COVID-19 pandemic period: A case study in Indonesia. Journal of Ethnic and Cultural Studies. 2020 Aug 1;7(2):90-109. https://eric.ed.gov/?id=ED606349

21. Kunju SS. Difficult, but, new experience: parents on homeschooling during lockdown. 2020, ND TV Education. Available at https://www.ndtv.com/education/home-schooling-duringlockdown-difficult-but-new-experience-say-parents-2213907

22. Rafi A, Varghese P, Kuttichira P. Concerns and confidences expressed by teaching staff about the shift of medical education to online mode in South India during the COVID 19 pandemic. Journal of ideas in health. [Internet]. 24Dec.2020
[29Aug.2021;3(Special2):272-5.

https://www.jidhealth.com/index.php/jidhealth/article/view/81

23. Bhamani S, Makhdoom AZ, Bharuchi V, Ali N, Kaleem S, Ahmed D. Home learning in times of COVID: Experiences of parents. Journal of Education and Educational Development. 2020 Jul 7;7(1):9-26. https://doi.org/10.22555/joeed.v7i1.3260

24. Garbe A, Ogurlu U, Logan N, Cook P. COVID-19 and remote learning: Experiences of parents with children during the pandemic. American Journal of Qualitative Research. 2020 Aug 9;4(3):45-65. https://doi.org/10.29333/AJQR/8471

25. Times of India. Tips for parents to help their children navigate online learning during the lockdown - Times of India. . (2020, April 2). https://timesofindia.indiatimes.com/lifestyle/parenting/toddler-year-and-beyond/tips-for-parents-to-helptheir-children-navigate-online-learning-during-thelockdown/articleshow/74943205.cms 